\title{
Iskonski antropološki put ostvarenja čovječnosti u misli Ivana Pavla II.
}

\author{
Emanuel Petrov*
}

\begin{abstract}
Sažetak
Polazeći od iskustva objektivnih posljedica stida, u radu se pokušava doći do iskustva iskonskog čovjeka i na tom temelju sagledati antropološke istine koje utječu na stvaranje zdrave čovječnosti i ostvarenje bogolikosti, kao uvjeta osobne sreće i blagostanja društva. Te istine pripadaju biti čovjekova bića te čine neprolazne vrijednosti, poput dostojanstva ljudskog tijela, vrijednosti čovjeka kao osobe, jasnog definiranja pojmova slobode i ljubavi te uloge roditeljstva, obitelji i vjere. Izgrađujući sretno čovještvo, te istine međusobno se prožimaju, ostvarujući sustav civilizacije ljubavi.

Ključne riječi: čovjek, odgoj, stid, tjelesnost, osobnost, društvenost, ljubav, Ivan Pavao II.
\end{abstract}

\section{Uvod}

Poznata izreka klasične antike, urezana na nadvratniku Apolonova hrama u Delfima, glasi: Gnothi seauton — Upoznaj samog sebe. Tijekom povijesti, svaki javni govor na temu izgradnje osobnosti i ostvarenja čovječnosti bio je prožet tom mudrošću. U antropološkim spisima Ivana Pavla II. ta izjava bila je kao nit vodilja koja za cilj ima pomoći čovjeku da upozna svoje čovještvo, dostojanstvo i ulogu u svijetu. Njegov je cilj vratiti čovjeka na iskon vlastitog dostojanstva, hrabreći ga nakon povijesnog pada utjelovljenom Riječju Božjom, da bi ga potom uputio prema vječnomu dioništvu na Božjem životu i njegovoj ljubavi. U tom konačnom bogolikom uzbiljenju čovjek bi trebao zasjati u punom sjaju nebeske proslave. Samo kroz perspektivu konačne proslave može se razumjeti život i dostojanstvo čovjeka, kao i njegovo dobro (Machinek, 2012, 59). Zbog toga u ovom radu, polazeći od objektivnih posljedica iskustva stida, ${ }^{1}$ želimo doći do onih iskonskih

* Emanuel Petrov, dr. sc., Katolički bogoslovni fakultet Sveučilišta u Splitu. Adresa: Zrinsko-Frankopanska 19, 21000 Split, Hrvatska. E-pošta: donepetrov@gmail.com

1 U literaturi na hrvatskom jeziku koju smo koristili u ovom radu te prema hrvatskom prijevodu Biblije u izdanju Kršćanske sadašnjosti, nazivi stid i sram, kao i njihove izvedenice, premda objektivno nisu, uglavnom se koriste kao istoznačnice. Stoga ćemo ih tako i koristiti. 
antropoloških istina ostvarenja čovječnosti, onako kako su predstavljene u iskonskom čovjeku i njegovom iskustvu, prije istočnoga grijeha, a prema misli Ivana Pavla II. Upravo iskonska istina, koja je iznad i prije svega, jedinstveno je područje ostvarenja čovječnosti i bogolikosti. Ista istina i nakon istočnoga grijeha, premda je obilježena mukom i trpljenjem, ostaje trajno mjesto izgradnje ljudskosti, te samim tim i put čovjekove konačne proslave.

Prema Ivanu Pavlu II., iskustvo iskonskog čovjeka, prije istočnoga grijeha, pripada temeljnoj teološko-antropološkoj istini čovjeka kao slike Božje. Čovjek je za njega prije svega tražitelj istine (FR 28). Istražujući nju, on zapravo teži za vječnošću i konačnim smislom čovještva, a to je dioništvo na Ljubavi. Iskonsko ljudsko iskustvo pokušava razumjeti čovjeka u onome što je bitno i posebno ljudsko, a ujedno egzistencijalno povezano s njegovim Stvoriteljem. U tom smislu, iskonsko ljudsko iskustvo otvara apsolutnu istinu koja oslobađa sumnji i daje sigurnost njegovoj egzistenciji (FR 27). Riječ je zapravo o tzv. adekvatnoj antropologiji, ${ }^{2}$ koja ističe važnost izvornog ljudskog iskustva. To temeljno iskustvo je čovjekov odgovor na Božju samoobjavu, ali i spoznaju dostojanstva samoga sebe kao slike Božje. Upravo čovjekova bogolikost i njegova ikonička struktura očituju apsolutnu izvornost onoga što on kao sakrament stvaranja jest. ${ }^{3}$ U skladu s tim, iskonsko ljudsko iskustvo je ontološka sastavnica ljudske naravi - onoga što prvi čovjek bitno jest, a očituje se u tri bitne sastavnice: iskonskoj Adamovoj samoći (Post 2,18-20), iskonskom jedinstvu muškarca i žene (Post 2,23) i iskustvu iskonske golotinje i nedostatka stida (Post 2,25) (Healy, 2013, 31). Pojava i iskustvo stida kao granično iskustvo i prag između iskona i povijesnosti predstavlja ključ razumijevanja čovječnosti (Ivan Pavao II., 2012, 117; 160). Povijesnost podrazumijeva povijest kakvu poznajemo, obilježenu vremenitošću, grijehom i trpljenjem. Obilježena je prošlošću, sadašnjošću i budućnošću. Do njzina konačnog ispunjenja čovjek kao slika Božja trpi u raskoraku između konačnog i beskonačnog, koje može ostvariti samo kroz ono iskonsko i bitno ljudsko.

Iz iskustva iskonske samoće izvire različitost čovjeka u odnosu na sva ostala stvorena bića (animalija) i njegova čežnja za družicom kao što je on (Post 2,20). Nijedno drugo stvorenje nije moglo čovjeku odgovoriti darivanjem na njegovo osobno predanje u ljubavi. Takvo predanje predstavlja izvor spoznaje, kako vlastite osobnosti, tako i društvenosti (Post 2,23). Čovjek živi u stalnoj hermenutici

2 Kardinal Carlo Caffarra, profesor etike, nadbiskup Bologne i predstojnik Instituta za proučavanježenidbe i obitelji „Ivan Pavao II.“ definira „adekvatnu“ antropologiju Ivana Pavla II. kao nešto posebno kršćansko. Riječ je o antropologiji koja nastoji shvatiti i predstaviti cjelovitog čovjeka u onom što je bitno ljudsko, a upravo to predstavlja njegov iskon. Adekvatna antropologija se dakle temelji na bitno ljudskom iskustvu i djeluje po načelu redukcije u vidu utvrđivanja trajnih značenja ljudskog postojanja. K tomu, budući da Krist otkriva čovjeka njemu samomu i objavljuje mu njegov uzvišeni poziv (usp. GS 22), čovjek se potpuno razotkriva tek u svjetlu Utjelovljene Riječi (Caffarra, 2012, 14-25).

3 Kad Ivan Pavao II. govori o sakramentu stvaranja, tu je riječ o čovjeku prije Adamova grijeha i prvog pada. Temeljno iskustvo čovjekove bogolikosti bitno je u shvaćanju konačne objave čovjekove kristolikosti u Kristovom pashalnom misteriju (Ivan Pavao II., 1982, 6). 
darivanja i prihvaćanja darovanoga, što se osobito odražava na njegovu tjelesnost, spolnost i izgradnju jednog tijela (Raming, 2006, 38-39). Stoga upravo u tom ženidbenom značenju tijela ${ }^{4}$ nalazi Ivan Pavao II. ključnu istinu o iskonskom čovjeku kao slici Božjoj, ali i trajno mjesto ostvarenja čovječnosti.

Ako se svemu navedenomu pridoda činjenica da biblijska pripovijest samo arhetipski smješta taj polazišni događaj iskonske samoće u društveni kontekst jednog bračnog ljudskog para - Adama i Eve, posljedice njihova iskustva pogađaju i čitav ljudski rod, sve njihove potomke, tj. kompletnu civilizaciju i društvenost (Runje, 2016, 398-399). Nužnost otkrića i kvalitetnog vrednovanja stida u procesu ostvarenja čovječnosti te spoznaja iskonske nepatvorene društvenosti, ključna je za izgradnju vlastite osobnosti kao i izgradnju civilizacije ljubavi.

Na temelju izrečenoga u radu ćemo pokušati razložiti sustav iskonskih antropoloških istina na kojima počiva ostvarenje čovječnosti i istinske bogolikosti. Pri tome se neće ulaziti u problematiku i metodologiju odgoja, nego ćemo se zadržati na iskonskim kvalitetama čovjeka, koje se otkrivaju prelazeći granično iskustvo stida. U prvom poglavlju promotrit ćemo objektivne posljedice koje objavljuje iskustvo stida. Riječ je o poremećenom iskonskom skladu između tjelesnosti i osobnosti, kao i o mukotrpnosti nužnog ostvarenja čovječnosti u novonastalim prilikama. O sustavu antropoloških istina na temelju nepostojanja stida u prvih ljudi (Post 2,25) raspravljat ce se u drugom poglavlju rada. Izvorno ljudsko tijelo otvara riznicu osobnosti, komunikacije (davanja i primanja), proegzistencije kao roditeljstva te afirmaciju osobe u slobodi i sebedarju, što konačno znači dioništvo u Ljubavi i Životu. To poglavlje predstavlja jezgru rada. Zaključno u tom poglavlju prepoznaje se iskonski antropološki put ostvarenja čovječnosti kao pravo i dužnost suvremenih roditelja i Crkve, a sve u službi izgradnje društva kao civilizacije ljubavi. Stoga u zaključku našeg rada samu čovječnost definiramo kao ostvarenje dioništva na Ljubavi.

\section{Objektivne posljedice iskustva stida}

Potpuno nova situacija u kojoj se našao povijesni čovjek zasvjedočena je svetopisamskim riječima: »Tada im se oboma otvore oči i primijetiše da su goli; spletu smokvina lišća i naprave sebi pregače« (Post 3,7). Takvo iskustvo otkriva ogoljenost vlastitog ,ja“ i posljedica je prijevare i neuspjeha očekivanja od sebe samoga »postati kao Bog « (Tognacci, 2016, 457). Sukladno takvoj tragičnoj spoznaji čovjek dolazi do potrebe da sadržaje koji su inače izvanjski, kao što je čovječje tijelo i njegove muške ili ženske vlastitosti, sakrije u vlastitu nutrinu. Zbog te činjenice govorimo o stidu tijela koji je direktno povezan sa spolnim stidom. Budući da je osoba biće koje, osim svojeg očitog ,javnog“ postojanja, posjeduje

4 Kad Ivan Pavao II. govori o ženidbenom značenju ljudskog tijela, riječ je o objavi i svjesnoj življenosti čovjekove tjelesnosti, koja kao bitnu sastavnicu uključuje spoznaju muškosti i ženskosti kroz međusobno darovanje i lišenost stida. Pri tom nije riječ o bestidnosti, nego o iskonskom značenju čovjekove tjelesnosti prije prvog pada te gledanju i doživljavanju drugoga Božjim pogledom. 
samo njemu vlastitu intimu (Wojtyła, 2009, 175), kad govorimo o pojavi stida, riječ je o kategoričkoj promjeni u čovjekovu doživljavanju, shvaćanju, a samim time i ponašanju. Kako je tu riječ o strahu ili bojazni koja se pojavljuje u čovjekovoj nutrini zbog njegove vanjštine, govorimo i o stidu doživljaja. On obuhvaća druga područja intime, poput misli, osjećaja i vlastitih nakana. Reflektira se kao nakana skrivanja onih reakcija i doživljaja u kojima se ističu odnosi prema tijelu kao prema uporabnom predmetu (Wojtyła, 2009, 189).

\subsection{Specifično ljudski pogled umjesto gledanja Božjim očima}

Stid uključuje posebno ograničenje vida tjelesnim očima. Ogoljenost, kojoj je postao svjedokom, unosi nemir u njegov izvorni sklad. I sam pogled čovjeku može nauditi. Njegov pogled nije više gledanje Božjim očima kroz otajstvo stvaranja, niti je u svojoj punini i jasnoći izvor spoznaje samoga sebe i vrelo usrećujuće radosti (Ivan Pavao II., 2012, 126). Takav novi specifično ljudski pogled opterećen je iskustvom povijesne požude, koja prema jahvističkom tekstu ima „spolno“ obilježje te donosi teškoću uočavanja biti vlastitog tijela i raskid njegova duhovnog i tjelesnog sklada. Požuda pogađa čovjekovu slobodu i prijeti razaranjem njegova subjektiviteta. Stid čovjeka sili da vrijednosti po kojima se otvarao drugomu biću kao što je on, smatra ugroženima, te ih krije u svojoj nutrini (Ivan Pavao II., 2012, 220-223). A upravo otvaranje i darivanje tih vrijednosti predstavlja ključ spoznaje i osobne radosti.

\subsection{Strah za vlastito „ja“ subjekta i krah zajedništva}

Iskustvo stida zadire u temeljne odnose iskonskog jedinstva muškarca i žene, ali narušava i čovjekov odnos s drugim stvorenjima, jer je prestao biti iznad svijeta živih bića i postao podložan nagonima. Zloporaba slobode urodila je sveopćom napetošću i konfrontacijom: čovjeka protiv Boga, tijela protiv duha, nagona protiv razuma i volje. Samim time stid je involviran u globalizirani svjetski društveni sustav te ga Papa s pravom naziva »kozmičkim stidom « (Ivan Pavao II., 2012, 218). Upravo to označava »vrijeme i prostor « stida (Bilokapić, 2016, 432). Ipak, korijen narušenih odnosa prije svega je u ugroženosti osobe. U tom smislu, Ivan Pavao II. precizira: »U iskustvu stida ljudsko biće doživljava strah pred „drugim ja“ (primjerice žena pred muškarcem) i to je bitno strah za svoje ,ja“. Stidljivošću ljudsko biće gotovo nagonski potvrđuje potrebu za potvrđivanjem i prihvaćanjem toga ,ja“ prema njegovoj pravoj vrijednosti. To istodobno doživljava izvana i u sebi, u odnosu na „drugoga“" (Ivan Pavao II., 2012, 119). Kroz iskustvo straha za vlastitu osobnost i identitet izvire i žaljenje za iskonskim skladom i jedinstvom, ali i mukotrpnost nužnog ostvarenja istoga u novonastalim povijesnim prilikama.

\subsection{Strogi sud umjesto osobne sreće}

Osjećaj stida korjenito mijenja dimenziju ljudske moralne savjesti, koja od izvora ljudske sreće postaje neumoljivi sudac. Pomanjkanje sreće valja tražiti u narušenoj slobodi, a samim time i neuravnoteženosti slobodnog darivanja i pri- 
hvaćanja druge osobe radi nje same. Nasuprot tomu, povijesni čovjek vrlo često gubi svoj subjektivitet i postaje drugomu »predmet radi mene«, »predmet privlačnosti i požude « i »neovlaštenog prisvajanja«, a kao takav spušta se na razinu animalija (Ivan Pavao II., 2012, 151). Jednom riječju, postaje objekt i uporabni predmet, a blistavi sjaj milosne čistoće srca, izvorne nevinosti i savršenog ethosa darivanja, biva zastrt velom stida. Požuda kao prisila tijela sužava i ograničava njegovu samokontrolu, te pomračuje izvornu sreću i ljepotu muškosti i ženskosti kao izraz duha (Ivan Pavao II., 2012, 242).

\subsection{Iskustvo trpljenja $i$ smrt}

Paralelno s opterećenjem ženidbenog značenja čovjekova tijela nesklad zahvaća i njegov rađalački ciklus poznavanja-rađanja, što je zasvjedočeno biblijskim riječima: »Trudnoći tvojoj muke ću umnožiti, u mukama ćeš djecu rađati« (Post 3,16). Otkrićem otajstva stida čovjek tako spoznaje ključnu objektivnu posljedicu svojeg opterećenog identiteta, a to je trpljenje i smrtnost. Ipak, izvorni život čovjeku nije potpuno oduzet, nego biva povijestan, a to znači omeđen začećem, rođenjem i umiranjem te otežan perspektivom nasljedne grešnosti (Ivan Pavao II., 2012, 181-182).

\subsection{Ključni obrat: spoznaja nemira, ali i obrambeni mehanizam čovječnosti}

S momentom iskrenog ili lažnog pristupa tjelesnosti čovjek kao subjekt stoji i pada. Stoga u istoj činjenici tražimo i ključni obrat. Međusobno predánje u muškosti i ženskosti predstavlja ostvarenje čovjekove slobode (Vesely, 1996, 264). Prava sloboda je neraskidivo vezana uz nepovredivost subjekta i osobe, kako vlastite, tako i osobe drugoga, te uz temeljnu iskonsku istinu o čovjeku kao slici Božjoj. Upravo ta unutarnja istina, upisana u dubinu ljudskog srca i njegove tjelesnosti kao communio personarum, makar mukotrpno, boreći se za ravnotežu davanja i primanja ljudske ljubavi, taj prvotni odnos muškarca i žene ostaje trajno područje potvrđivanja subjektivne autentičnosti i obrane od svođenja na čisti predmet (Ivan Pavao II., 2012, 247-248). Budući da stid nadolazi paralelno s požudom, može ga se promatrati i pozitivno, kao obrambeni mehanizam koji štiti od njezinih posljedica i pomaže u borbi za ostvarenje ravnoteže iskonske nevinosti, a samim tim i ikoničke strukture čovjeka (Petrov, 2017, 79). Stoga je važno primijetiti da izvorno ženidbeno značenje tijela nije u čovjeku potpuno razrušeno i ugušeno požudom, nego je postalo ugroženo neprikladnošću za prihvaćanje dara i potpunog ostvarenja. U tom istom ženidbenom značenju tijela i nadalje je ključ dodira s čovjekovim iskonom, njegovom cjelovitošću i bogolikošću. Život koji je čovjek baštinio od otajstva stvaranja nije mu oduzet, nego, premda opterećen smrtnošću, iznova mu je dan kao zadaća vlastitog ostvarivanja čovještva (Ivan Pavao II., 2012, 180-181). Stoga je i sam stid u službi cijele osobe, štiti ženidbeno značenje njezina tijela, ali i njezino otajstvo i ljubav. Stid je tako obrambeni mehanizam osobnoga "ja” pred izloženošću društvenim opasnostima, zaštita pojedinca i njegove individualne vrijednosti od sfere općega, zaštita osob- 
ne intime od profanizacije i vulgarizacije, a istovremeno je očuvanje i promocija čovještva (Bilokapić, 2016, 429-430).

\section{Sustav iskonskih antropoloških istina (Post 2,25)}

Biblijsko izviješće: »A bijahu oboje goli — čovjek i njegova žena — ali ne osjećahu stida «(Post 2,25) iskonska je istina vezana uz čovjekovo tijelo, a nastavlja se na prva dva temeljna iskustva samoće i jedinstva muškarca i žene (Ivan Pavao II., 2012, 115). Istovremeno je i ključ za njihovo puno i cjelovito razumijevanje. Naime, po dubini iskonske samoće čovjek žudi za međusobnim darivanjem koje izražava po ljudskom tijelu u cjelovitoj izvornoj istini svoje muškosti i ženskosti, što je samim time izraz njegova postojanja kao osobe (Ivan Pavao II., 2012, 133134). ${ }^{5}$ U skladu s navedenim, vidljivo je da su prvi ljudi imali svijest i iskustvo tijela: muškarac iskustvo ženskosti, ali i obrnuto (Ivan Pavao II., 2012, 116). Riječ je zapravo o spoznaji, znanju i gledanju Božjim očima kroz otajstvo stvaranja, u savršenoj ljubavi i sebedarju, bez iskustva grešnosti. Uzajamno gledanje nije samo dioništvo u izvanjskoj percepciji svijeta, nego je i unutarnja dimenzija dioništva u viđenju samog Stvoritelja, o kojem govori izvještaj prvog poglavlja Knjige postanka (Post 1,31) (Ivan Pavao II., 2012, 125-126). Zato neosjećanje stida nikako ne predstavlja njegovu nerazvijenost ili bestidnost. Papa izrijekom tvrdi: »Riječi iz Post 2,25, nisu osjećali stida, ne izražavaju manjak, naprotiv, služe za označavanje osobite punine svijesti i iskustva, poglavito punine shvaćanja značenja tijela, povezane s činjenicom da bijahu goli« (Ivan Pavao II., 2012, 120). Punina shvaćanja i iskustva označava čistu i nesmetanu međusobno komplementarnu komunikaciju, u punini međusobnog zajedništva i povjerenja (Runje, 2016, 398). Čovjek kao osoba predstavlja se u potpunoj otvorenosti i kristalnoj jasnoći svojeg tijela, bilo muškog ili ženskog, te je ona bitna dimenzija čovjekove prirode i identiteta (Machinek, 2012, 53). Takvo čisto iskustvo i spoznaja na temelju ničim ometane percepcije tijela ključni je preduvjet jednakog dostojanstva subjekata i njihove bogolikosti, te put ostvarenja poziva na međusobni slobodni odnos i proegzistenciju u ljubavi (Healy, 2013, 33-34; Ivan Pavao II., 2012, 131). Stoga izgradnja takvog dostojanstva i sakramentalnosti čovjeka kao dioništva na Ljubavi predstavlja temelj sustavu iskonskih antropoloških istina čovječnosti i vodi do radosne čovječnosti svakog konkretnog pojedinca, a tako i društva u cijelosti.

\subsection{Tijelo izražava osobu}

Iskonska nevinost percepcije po tijelu kao iskonsko gledanje golog tijela drugog ljudskog bića i uz njegovu/njezinu pomoć čovjeku istodobno omogućuje spoznaju vlastitog čovještva i osobnosti. Prema jahvističkom tekstu, tijelo izražava osobu, što je u skladu s čovjekovim ushitom »evo mesa od mesa mojega

5 Papin govor o ostvarenju identiteta osobe u punini kroz čin osobnog darivanja utemeljen je na nauku Drugog vatikanskog sabora, koja je osobito izražena u GS 24. 
i kosti od mojih kostiju « (Post 2,23) (Ivan Pavao II., 2012, 133). Takvom interpersonalnom komunikacijom predstavlja se čovjek kao subjekt i čimbenik, bez da ga se pretvori u objekt, što je tragična činjenica nastala nakon razdora i opasnost je povijesnog vremena. Čisto tijelo s bitnim obilježjem njegove spolnosti, kao izvanjsko očitovanje osobe, u izvornom smislu je sakrament — vidljivi znak osobe u njezinu ontološkom i egzistencijalnom identitetu i stvoreno kao znak i subjekt istine, svetosti i otajstva skrivena u Bogu (Ivan Pavao II., 2012, 166-168). U takvom izvornom stanju apsolutno je suglasje i komplementarnost u čovjeku, onog što je duhovno i osjetilno, to jest onog što utemeljuje osobu u ljudskom te onog što je u čovjeku određeno spolnošću. »Ljudsko tijelo sa svojom spolnošću, muškošću i ženskošću, promatrano u otajstvu stvaranja«, tvrdi Papa, »nije samo vrelo plodnosti i prokreacije kao u svem ostalom prirodnom poretku, nego 'od početka' sadrži pridjev 'ženidbeni', tj. sposobnost izražavanja ljubavi: upravo one ljubavi u kojoj čovjek-osoba postaje dar i — po tom daru — ostvaruje smisao svojega bića i postojanja« (Ivan Pavao II., 2012, 136). To iskustvo ženidbenog zajedništva muškarca i žene na samom početku čovjekove egzistencije predstavlja prvotnu svijest čovjekova identiteta (Ivan Pavao II., 2012, 125-126). ${ }^{6}$ Kroz temeljni znak izvornog identiteta i među(o)sobne komunikacije koju tijelo ostvaruje, čovjek se predstavlja kao slika Božja. U iskustvu jedinstva i zajedništva on se otkriva kao slika zajedništva Presvetog Trojstva. Tako communio personarum biva iskonski znak Stvoriteljeve volje i istovremeno vrhunac komunikacije koju čovjek kao biće može ostvariti. Ivan Pavao II. u tom kontekstu svjedoči: »Toj punini 'izvanjske' percepcije, izražene tjelesnom golotinjom, odgovara 'unutarnja' punina viđenja čovjeka u Bogu, tj. prema mjeri 'slike Boga' (usp. Post 1,17)« (Ivan Pavao II., 2012, 123). Papa tako naglašava čistoću čovjekove iskonske osobnosti i savršenost međusobnih odnosa. Iz toga slijedi da je suglasje čovjekova tijela i njegove osobnosti izraz onog savršenog zajedništva i one jednostavnosti koja je u Bogu. Izvorno suglasje prema tomu očituje čovjekovo dioništvo na Božjem životu (Stala, 2014, 145). Stoga je na putu izgradnje čovječnosti ključno prepoznati važnost čiste iskonske tjelesnosti, što vodi ostvarivanju njezina sklada s osobnošću, tj. do ostvarenja čovječnosti.

\subsection{Egzistencijalna sposobnost darivanja}

Ljubav (ex nihilo) je polazišna točka stvaranja. Čista interpersonalna komunikcija i međusobno darivanje muškarca i žene čine kontinuitet te iskonske stvaralačke Ljubavi. Takav jedinstven odnos pokreće konkretno dobro i u dobru uživa. Ta vrijednost za Ivana Pavla II. iznimno je važna jer smatra da je stvaranje iskonski dar zbog pojavnosti čovjeka kao slike Božje. Kao takav, čovjek ima

6 Bitna stavka čovjekova identiteta upravo je ljubav, iz koje je pozvan u postojanje i čijemu je svjedočanstvu u svijetu usmjeren. To je nit vodilja koju Ivan Pavao II. naglašava od početka svojeg pontifikata, osobito u svojoj programatskoj enciklici Redemptor hominis, gdje izričito tvrdi: »Čovjek ne može živjeti bez ljubavi. Sam po sebi on ostaje neshvatljivo biće, život mu je lišen smisla ako mu se ne objavi ljubav, ako se ne susretne s ljubavlju, ako je ne iskusi i ne usvoji, ako u njoj živo ne sudjeluje« (RH 10). 
sposobnost razumijevanja smisla Božjeg darivanja. Bog iz ništavila zove čovjeka na postojanje i na taj poziv čovjek odgovara istim jezikom, to jest darivanjem (FC 11; Ivan Pavao II., 2012, 128-129). Stoga se bit čovjekove egzistencije ostvaruje isključivo i samo u postojanju s nekim ili za nekoga. U skladu s čovjekovim sebedarjem, postoji potreba za primanjem i prihvaćanjem čistog osobnog dara drugoga. Darivanje i prihvaćanje se prožimaju jer se darivanje pretvara u prihvaćanje, a prihvaćanje u darivanje. U takvom isprepletenom međuodnosu nalaženje samoga sebe u vlastitom darivanju postaje vrelo novog sebedarja, a time i obogaćivanja (Ivan Pavao II., 2012, 151-152). Čovjekova egzistencija tako postaje proegzistencija. »Zajedništvo osoba znači postojanje u uzajamnu 'za', u odnosu uzajamna darivanja«, tvrdi Papa (Ivan Pavao II., 2012, 132). Put je to prema ostvarenju iskonskog Božjeg poziva na postojanje u ljubavi (Aračić, 1982, 524). Nago čovjekovo tijelo je svjedok slobodnog stvaranja iz ljubavi kao temeljnog dara, a spolnost kao iskonsko izražavanje tog stvarateljskog darivanja ljubavi, odnosno svijesti čovjeka o darivanju od strane Stvoritelja (Ivan Pavao II., 2012, 133; 136). Primanje i življenje tog dara razlikuje čovjekovu plodnost i prokreaciju, to jest njegovu autoreprodukciju, od sveg ostalog stvorenog prirodnog poretka. Samo čovjek ima sposobnost komunikacije ljubavi i u tom procesu formira vlastitu osobnost u kontekstu ostvarenja čovječnosti.

\subsection{Autonomnost i sloboda u sebedarju}

Samo slobodan čovjek može se istinski darovati i primiti dar. Inače se takav proces pretvara u laž. Stoga se preko iskonske slobode dolazi do nesebičnog darivanja. Iskonski čovjek je slobodan po slobodi stvoriteljskog dara. On je jedino biće stvoreno radi njega samog i sebe može spoznati samo živeći slobodu u darivanju (Ivan Pavao II., 2012, 138). Iz navedenoga proizlaze dvije ključne istine takvog darivanja: autonomnost i sloboda čovjeka kao subjekta. Čovjek je sposoban prihvaćati i biti dar radi samog sebe i svojeg identiteta (Stala, 2011, 16). U realizaciji istoga ne smijemo zaboraviti njegovo iskustvo iskonske samoće i potrebe za drugim ,ja“ te iskonsko jedinstvo koje iz toga proizlazi. Katalizator tog procesa je iskonska sloboda. Ivan Pavao II. naglašava:

Muškarac i žena u svojemu kontekstu blažene radosti 'početka' slobodni su samom slobodom za darivanje. [...] Ovdje slobodu shvaćamo prije svega kao vladanje samim sobom (auto-dominatio). Pod tim vidom ona je neophodna da bi čovjek mogao 'darivati sebe samoga', da bi mogao postati dar, da bi mogao (podsjećajući na riječi Sabora) 'potpuno naći sebe samoga iskrenim darivanjem samoga sebe'. [...] Unutra slobodni od prisile vlastitoga tijela i spolnosti, slobodni slobodom dara, muškarac i žena mogli su uživati svu istinu, svu ljudsku očitost, kao što ih je Bog-Jahve njima objavio u otajstvu stvaranja (Ivan Pavao II., 2012, 137-138).

Konkretno sloboda se sastoji u razmjeni osobnih darova u tjelesnosti s iznimnom pozornošću na drugoga, kako to odgovara samoj biti dara (Ivan Pavao II., 2012, 150). Samo takvo darivanje u slobodi tvori čovještvo kao communio personarum - dar u svoj istini, dostojanstvu i očitosti muškog i ženskog tijela kao dioništvo slobodnog čina Božje volje i slika Presvetog Trojstva. 


\subsection{Sreća}

Spoznaja osobnosti po ljudskom tijelu u iskonu, prije pojave stida, predstavlja za čovjeka usrećujući trenutak. Njegova sreća je utemeljena na svijesti dioništva na izvornoj i vječnoj stvarateljskoj Ljubavi, prema kojoj su muškarac i žena prvi svjedoci vlastite prokreacije. Na temelju toga Ivan Pavao II. tvrdi da je sreća ukorijenjenost u Ljubav (Ivan Pavao II., 2012, 144). Neizostavan je uvjet takve ukorijenjenosti milost izvorne nevinosti i pravednosti, koja označava izvorno čovjekovo sudjelovanje na Božjem životu i njegovoj svetosti kod Boga. Njegovo čisto tijelo, po svojoj vidljivoj muškosti i ženskosti, kao znak, prenosi nevidljivo otajstvo odvijeka skriveno u Bogu u vidljivi svijet. S obzirom na to da izvorna nevinost uključuje doživljavanje i gledanje drugih i svijeta Božjim stvarateljskim očima punim ljubavi, koja potpuno potvrđuje osobnost drugoga bez napasti svođenja čovjeka na objekt i uporabni predmet, sreća prije svega zahvaća čovjekovo srce. Očituje se kao izvorna ispravnost ljudskog djelovanja i vedro svjedočanstvo savjesti, koje čovjeka nema za što optužiti, nego ga usrećuje (Ivan Pavao II., 2012, 147-148; 161). U skladu s tim, sreća iskonskog čovjeka pokazuje i određuje savršeni ethos sebedarja kao čistoću srca, koja u međusobnom tjelesnom darivanju i prihvaćanju čuva subjektivnost muškarca i žene od pretvaranja u predmet ili objekt. Sama činjenica da pri tom izvornom činu „nisu osjećali stida“ dokazuje da je čovjek subjekt, i to subjekt kao muškarac i subjekt kao žena (Ivan Pavao II., 2012, 159-160). Samo subjekt može ljubiti. Poziv na čistu ljubav i isključivo oživotvorenje te ljubavi u sebedarju stoga su dvije ključne sastavnice iskonske čovjekove sreće (Frkin, 1994, 598). Takvoj sreći prednjači sloboda, a za sobom povlači bitan osjećaj za odgovornost, što je također u skladu s ljubavlju i uzvišenim pozivom ostvarenja čovječnosti (Tomašević, 2009, 62).

\subsection{Radalačko jedinstvo prokreativnih subjekata}

Objava osobe kao dara u spoznaji tjelesnosti i usrećujući trenutak s tim u vezi nije svrha sam sebi. Nakon što je jahvistički izvještaj utvrdio istodobnu objavu i spoznaju čovjekove tjelesnosti i osobnosti, navedena je svrhovitost takvog darivanja koje svoje ishodište ima u Stvoriteljevoj ljubavi: »Stoga će čovjek ostaviti oca i majku da prione uza svoju ženu i bit će njih dvoje jedno tijelo« (Post 2,24). Na temelju tog izvještaja Ivan Pavao II. zaključuje: »Međusobno se sjedinjujući tako blisko da postaju 'jedno tijelo', oni će u određenom smislu svoje čovještvo podložiti blagoslovu plodnosti, tj. 'prokreacije' « (Ivan Pavao II., 2012, 134135). Važno je uočiti dinamizam spolnosti, koji ima dvostruki smisao: smisao sjedinjenja koji vodi smislu rađanja (HV 12; Fuček, 1985, 12). Od čina tjelesnog predánja nedjeljivo je potpuno osobno darivanje, kao iskonska istina koja ostvaruje čovjekov identitet. Oskudno tjelesno predánje bez osobne dimenzije je laž (FC 11; 17). Svoju osobnost muškarac otkriva poznavanjem darovane mu žene (Post 4,1). Riječ je o takvom intimnom međusobnom sjedinjenju da tvore jedno tijelo. Nužno za ostvarenje jednog tijela je dvostrukost spola. Po svojoj muškosti i ženskosti u tom iskonskom poznavanju čovjek doživljava uzvišenost 
vlastitog tijela, kojim gotovo izgrađuje jedinstven subjekt, premda u tom sjedinjenju ostaju dva različita subjekta. Riječ je o međusobnom i uzajamnom otkrivanju osobnog identiteta i konkretnosti u dubini vlastitog ,ja“, koje se otkriva po njihovoj spolnosti. U toj temeljnoj stvaralačkoj istini prezentiran je Božji naum da kroz usađenu međusobnu privlačnost, želju i ljubav, čvrsta i čista rađalačka povezanost muškarca i žene vodi čvrstoj vezi sa svojim Stvoriteljem (Fuček, 1985, 9). To ženidbeno iskonsko sjedinjenje prožima cjelovitog čovjeka: njegovo tijelo i nagone, osjećaje i osjećajnost, čežnju duha i volje, da bi takvo odražavalo vjernost Božje ljubavi, njezinu trajnost i plodnost (FC 13). Poznavanje vlastite osobnosti kroz izgradnju jednog tijela zahtijeva aktivan, jedinstven i neponovljiv subjekt (Ivan Pavao II., 2012, 166-168). Pasivnomu predmetu takva izvorna spoznaja nije moguća. Prema tomu, cilj je da čovjek osobno i u izgradnji jednog tijela preuzme ulogu prokreativnog subjekta u svijetu, kako ne bi bio pasivan promatrač ili objekt s kojim se tjelesnost poigrava.

\subsection{Majčinstvo i očinstvo kao osobna i društvena afirmacija}

Muškarac i žena međusobno se upoznaju kroz tjelesno sjedinjenje, ali i kroz treće rođeno od njih dvoje. Takvo poznavanje ostvaruje se u zajedništvu sa svojim Stvoriteljem (Ivan Pavao II., 2012, 173). Međusobnim sjedinjenjem prokreativnih subjekata svaki se put u muškarcu i ženi reproducira ista slika Boga, koji je sazdao čovještvo prvog čovjeka, a Stvoriteljevim se darom prenosi i na novog čovjeka (Ivan Pavao II., 2012, 174-176). Papa to naziva biblijskim ciklusom „poznavanja-rađanja“, koji je sam prag čovjekove povijesti na zemlji, a otkriva u muškosti značenje očinstva i u ženskosti značenje majčinstva (Ivan Pavao II., 2012, 177-178; 181). Uz sudjelovanje u iskonskoj stvarateljskoj ljubavi kao izvoru čovjekova života, vezano je dakle reproduciranje čovjekove osobne samospoznajne radosti, ali i nastavak stvaralačkog kontinuiteta u novoj osobi. Taj radostan čovjekov trenutak pripada samoj biti čovječnosti jer izvire iz iskonskog otkrića drugog bića kao što je on. Osim što potvrđuje vlastitu tjelesnu muškost ili ženskost, pripada i afirmaciji osobe. Afirmacija osobe prihvaćanje je dara, koji uzajamnošću stvara zajedništvo osoba. Takvo zajedništvo gradi se iznutra, uključujući svu čovjekovu izvanjskost, to jest sve što tvori čistu i jednostavnu tjelesnu nagost u njegovoj muškosti i ženskosti, ali prije osjećaja stida (Ivan Pavao II., 2012, 139-140). Budući da logika ljubavi uključuje troje: darivanje, stvarnost ljubavi i darivanje novog života, ne može i ne smije se jedno od drugoga odvajati (Aračić, 1982, 528).

Isti život i ljubav Boga oni [roditelji, op. a.] prenose na potomstvo. Dakako, kad kažemo 'isti', uvijek se teološki i filozofski pretpostavlja analogija bića i analogija vjere, da ne bismo shvatili kako je Božji život i život čovjeka na istoj jednoznačnoj razini. Ali misterij i jest u tome što supruzi kroz svoju ljubav u darivanju rađanja prenose ‘život' i ‘ljubav' Boga, a ne nešto drugo (Fuček, 1985, 9).

Iz toga slijedi da povezanost, kontinuitet i ikonička struktura vlastitog subjekta, koji se daruje drugomu slobodnomu subjektu, afirmira i sebe i drugoga. Takva afirmacija osobe u proegzistentnom predanju reproducira se rađanjem 
u novoj osobi, koja je također slika Božja, ali i slika vlastitih roditelja, i nastavlja u njezinu formiranju čovječnosti (Stala, 2011, 16-17). »U tom novom čovjeku — rođenom od žene-roditeljke djelovanjem muškarca-roditelja — svaki se put reproducira ista 'slika Boga', onog Boga koji je sazdao čovještvo prvog čovjeka« (Ivan Pavao II., 2012, 175). Stoga temelj iskonske afirmacije osobe čini upravo njezina proegzistencija, čiji je konačni iskon u stvaralačkoj ljubavi, a ostvaren je u novom čovjeku.

\subsection{Roditeljski odgoj za civilizaciju ljubavi u vjeri}

Kroz sustav iskonskih antropoloških istina koje proizlaze iz iskonskog iskustva čovjeka kristalizira se prostor i vrijeme ostvarenja čovječnosti. Prije svega, takvo nastojanje neodvojivo je od religioznog područja, jer se odnosi na odgoj za civilizaciju ljubavi i ostvarenje poziva za ljubav u svakom čovjeku. A istinska Ljubav je sam Bog (1 Iv 4, 8.16). Nadalje formiranje čovječnosti nužno je smjestiti unutar obitelji (Stala, 2014, 141). Otac i majka imaju neoborivo pravo i dužnost kao prvi svjedoci ljudskog identiteta svojoj djeci posredovati iskonsko dostojanstvo života.

Roditeljsko odgojno pravo i dužnost nešto je izvorno i prvobitno, nezamjenjivo i neotuđivo, jer izvire iz očinstva i majčinstva. Uzajamno očinstvo i majčinstvo postižu svoje ispunjenje u odgoju, a samo nastojanje oko odgoja djece pridonosi potpunomu dioništvu odgajanika na istinskom ljudskom životu i čovještvu. Sveti Papa zato naglašava da je takvo neprestano „stvaralaštvo“ čudesan plod Božjeg Duha, koji daje vrlo istančan osjećaj za nove potrebe i patnje društva te prikladan odgovor na njih (FC 36, 39; Aračić, 1982, 528). U tom kontekstu, ostvariti čovještvo znači djelotvorno pomoći osobi da živi ljudski život u punini. A punina života očitovana je u njegovim iskonskim istinama i dioništvu na ljubavi. Kao zaključak nameće se uvjerenje da jedino religiozna perspektiva koja vodi računa o svakom i konkretnom čovjeku kao slici Božjoj, kroz ostvarenje prava i dužnosti roditelja, može stvoriti uvjete za realno ostvarenje čovječnosti i postojanje civilizacije ljubavi.

\section{Zaključak}

Bitnu razdjelnicu između iskona i povijesnosti kakvu poznajemo nalazimo u pojmu stida. Ivan Pavao II. naziva ga graničnim iskustvom. On obznanjuje objektivne posljedice prvog pada kojima povijesni čovjek biva izložen. Premda neprestano upozorava na njih, bitno ga je istovremeno prepoznati kao nezaobilaznu i neophodnu pozitivnu akciju zaštite suglasja čovjekove tjelesnosti i osobnosti, što predstavlja bit njegove čovječnosti i ostvarenje iskonskog poziva biti slika Božja. Iskustvo stida obznanjuje i mukotrpnost ostvarenja istoga u novonastalim povijesnim prilikama. Stoga je on istovremeno prag preko kojeg valja prijeći da bi se došlo do iskonske čovječnosti neopterećene osjećajem stida. Takvo izvorno iskustvo čovjeka viđenog Božjim očima otkriva temeljne istine čovjekove ikoničke strukture, njegove osobnosti i društvenosti. Na istom 
području, koje je bitno obilježeno hermeneutikom darivanja, čovjek odgovora na poziv ljubavi i čovječnosti te ponovno ostvaruje vlastitu bogolikost. Upravo otajstvo slike Božje sa sobom nosi ključne osobitosti ljudskog tijela, koje je nedjeljivo od osobnosti čovjeka kao subjekta. Sustav istina koje objavljuje ljudsko tijelo temelj je osobnosti, komunikacije kao darivanja i primanja, sreće, slobode i sebedarja te u konačnici proegzistencije kao očinstva i majčinstva. Sve te istine možemo svrstati pod zajednički naziv ženidbenog dara u ostvarenju dioništva ljubavi. Prema tomu, a budući da je Bog ljubav, iskonski antropološki put odgoja čovječnosti nedjeljiv je od religioznog i roditeljskog područja i redovito je u službi civilizacije ljubavi. Činjenica da Bog kroz ljubav ulazi u odnos s čovjekom, tražeći istovremeno njegov odgovor, predstavlja ljubav kao najveći i najplemenitiji oblik kulture života. Upravo je osoba osnovni „građevni materijal“ života i ljudskog djelovanja. A potpuna i nužna afirmacija ljudske osobe i njezine čovječnosti moguća je i shvatljiva samo u njezinoj ontološkoj, moralnoj i psihološkoj povezanosti s osobnim Bogom, kakva je življena u iskonu (Stala, 2015, 472). Takva čovječnost čvrsto je usmjerena na cjelovitog čovjeka, na osobu. Spolnost je bogatstvo cjelovite osobe — tijela, osjećaja i duše; svoje najdublje značenje očituje kad osobu dovede do sebedarja u ljubavi. Čovječnost tako pretpostavlja nevinost i čistoću, kao krepost koja razvija istinsku zrelost osobe, osposobljavajući je da poštuje i promiče ženidbeno značenje tijela. U tom kontekstu također valja primijetiti i znakove Božjeg poziva na djevičanstvo. To je najviši oblik sebedarja i smisao ljudske spolnosti (FC 37). Sebedarje i nevinost su čimbenici koji predstavljaju prirodno iskustvo čovjeka i omogućuju mu pozitivan odnos sa svijetom i ljudima, a temelj su religioznog iskustva i odnosa s Bogom (Stala, 2015, 473). Udio osobe u punini ljubavi predstavlja njezinu vlastitu, ali i društvenu afirmaciju kao posebnost u nizu drugih stvorenih bića te označava kontinuitet ljubavi koja se prenosi rađanjem. Čovjek se tako istinski predstavlja kao jedino biće na zemlji kojeg je Bog htio radi njega samog da bi ga usrećio. To znači da je samo čovjek stvoren da živi zauvijek, jer je jedini pozvan uzeti eshatološkog udjela u Božjem životu. Na takav će način konačno i potpuno afirmirati svoju osobu u Bogu i baštiniti potpunu sreću (Pismo obiteljima 9). Drugim riječima, samo je čovjek, od sveg stvorenog svijeta, pozvan kao slika Božja biti sakramentom — vidljivim znakom. Taj znak u njemu je iskonska istina, koja nakon prvog pada i pojave stida postaje također i spasenjska. Ona se kao trajna istina, upisana u dubinu ljudskog srca i njegove tjelesnosti, bori za potvrđivanje čovječnosti, njegove autentičnosti kao subjekta, ostvarenje davanja i primanja međusobne ljudske ljubavi i konačno uzimanje udjela na vječnoj Ljubavi.

\section{Literatura:}

Aračić, Pero (1982). Neki putokazi brakovima i obiteljima u papinskoj pobudnici »Familiaris consortio« (Obiteljska zajednica). Obnovljeni život, 37, 6, 523-533.

Bilokapić, Šimun (2016), Značenje i funkcija stida iz perspektive moralne teologije. Crkva u svijetu, 51, 3, 426-452. 
Caffarra, Carlo (2012). Opći uvod. U: Ivan Pavao II., Muško i žensko stvori ih: Kateheze o ljudskoj ljubavi: Cjelovita teologija tijela: Svezak I. (str. 11-48). Split: Verbum.

FC. Familiaris consortio. U: Ivan Pavao II., Familiaris consortio: Obiteljska zajednica: Apostolska pobudnica o zadaćama kršćanske obitelji u suvremenom svijetu. Zagreb: Kršćanska sadašnjost, 2009.

FR. Fides et ratio. U: Ivan Pavao II., Fides et ratio: Vjera i razum: Enciklika svim biskupima Katoličke crkve o odnosu vjere i razuma. Zagreb: Kršćanska sadašnjost, 1999.

GS. Gaudium et spes. U: Drugi vatikanski sabor, pastoralna konstitucija (1) Gaudium et spes" (Radost i nada) o Crkvi u suvremenom svijetu (7. 12. 1965.). URL: https://zrno. wordpress.com/teoloske-teme/crkveni-dokumenti/dokumenti-drugog-vatikanskogsabora/gaudium-et-spes-1965/ (15.06.2017.)HV. Humanae vitae. U: Pavao VI., Humanae vitae - enciklika o ispravnoj regulaciji poroda. Zagreb: Kršćanska sadašnjost, 1968.

Frkin, Josip (1994). Pismo obiteljima pape Ivana Pavla II. Obnovljeni život, 49, 6, 591-601.

Fuček, Ivan (1985). Prenositi ili priječiti život? Pitanje »naravne« ili »umjetne« kontracepcije: (Komentar Familiaris consortia, br. 28-35). Obnovljeni život, 40, 1, 5-30.

Healy Mary (2013). Muškarci i žene su iz Edena: Studijski vodič za teologiju tijela Ivana Pavla II. Split: Verbum.

Ivan Pavao II. (1982). Ansprache bei der Generalaudienz am 6. Oktober 1982, L'Osservatore Romano, Die Wochenausgabe in deutscher Sprache, 12, 42, 25.

Ivan Pavao II. (2012). Muško i žensko stvori ih: Kateheze o ljudskoj ljubavi: Cjelovita teologija tijela: Svezak I. Split: Verbum.

Koprek, Ivan (2007). Antropologija u misli Ivana Pavla II. U: Ines Sabotič, Željko Tanjić i Gordan Črpić (ur.), Ivan Pavao II.: poslanje i djelovanje (str. 77-83). Zagreb: Glas Koncila.

Machinek, Marian (2012). Heilige und vorletzte Wirklichkeit: Einsatz Johannes Pauls II. für die Würde des menschlichen Lebens. The Person and the Challenges, 2, 1, 51-60.

Nimac, Stipe (1999). Pastoralno djelovanje u neredovitim situacijama prema »Familiaris consortio« (br. 79-84). Bogoslovska smotra, 69, 2-3, 407-424.

Petrov, Emanuel (2017). Affirmation of Humanity Based on Positive Education in Modesty According to Pope John Paul II's Teaching. U: Jadranka Garmaz i Alojzije Čondić (ur.), Challenges to Religious Education in Contemporary Society (str. 73-88). Split: Crkva u svijetu.

Pismo obiteljima. Ivan Pavao II., Pismo obiteljima pape Ivana Pavla II. Zagreb: IKA, 1994.

Raming, Ida (2006). Gleichrangig in Christus anstatt: Ausschluss von Frauen „im Namen Gottes“: Zur Rezeption und Interpretation von Gal 3,27f in vatikanischen Dokumenten. Berlin: LIT Verlag.

Reljac, Veronika (2009). Modaliteti obiteljskog pastorala. Riječki teološki časopis, 17, 2, 459-482.

RH. Redemptor hominis. U: Ivan Pavao II., Redemptor hominis - Otkupitelj čovjeka: Enciklika kojom se papa Ivan Pavao II. na početku svoje papinske službe obraća svojoj braći u biskupstvu, svećenicima, redovničkim zajednicama, sinovima i kćerima Crkve i svim ljudima dobre volje. Zagreb: KS, 1980.

Runje, Domagoj (2016). Stid u Post 2, 25 - 3, 21. Crkva u svijetu, 51, 3, 396-412.

Stala, Józef (2011). Die Person und die Herausforderungen der Gegenwart im Licht der Nachfolge und der Lehre des Heiligen Vaters Johannes Pauls II. The Person and the Challenges, 1, 1, 13-23.

Stala, Józef (2014). Richtungsweisende Merkmale zur religiösen Erziehung und Bildung im Lehrwerk von Papst Johannes Paul II. Bogoslovska smotra, 84, 1, 137-148. 
Stala, Jósef (2015). Punina postojanja osobe — civilizacija ljubavi u kontekstu postmoderne. Crkva u svijetu, 50, 3, 469-477.

Tognacci, Stefano (2016). Psihologija srama: glavni psihologijski i kulturološki vidovi. $\mathrm{Cr}$ kva u svijetu, 51, 3, 453-477.

Vesely, Ema (1996), Papa Ivan Pavao II. za novu kulturu života: Uz encikliku Evanđelje života. Obnovljeni život, 51, 3, 261-284.

Tomašević, Luka (2009). Filozofsko-teološki pogled na ljudsku spolnost i spolni odgoj. Služba Božja, 49, 1, 44-67.

Wojtyła, Karol (2009). Ljubav i odgovornost. Split: Verbum.

The Original Path to the Realization of Humaneness in the Thoughts of John Paul II

\section{Emanuel Petrov*}

\section{Summary}

This article provides an overview of anthropological truths based on the experience of original man which can be understood through the return to man's original state, before the first sin. Although, after the experience of shame, these truths have been burdened by pain and suffering and marginalised by contemporary society, they remain everlasting principles for the building of a humane society, the premise for personal fulfillment and the well-being of civilization as a whole. Original truths are inherent in human beings and provide them with perennial values such as the dignity of the human body, the value of the person, freedom and love which should be identified as the primary tasks of parenting, the family and the Church. These truths render humanity joyful and are intertwined, affecting a binding, continuous cycle which aims at the realization of human communion in the love of God and the revival of this very love through self-giving. This is what generates human subjectivity.

Based on the above claims, we aim to clarify the original anthropological truths and their significance in the process of cultivating humaneness. The first section refers to the importance of the original human experience. The second and the central section of the article deal with the cycle of anthropological truths based on the original absence of shame in the very first human beings (Gen 2:25). The original human body is the repository of an individual's values, communication, pro-existence associated with parenthood, and the affirmation of the person in freedom and self-giving, which ultimately lead to the communion of Love and Life. The third section refers to the original anthropological truth aimed at building a humane society as the primary task of parents and the Church, but all for the sake of society as a civilization of love.

Key words: man, cultivation, shame, human body, personality, sociability, love, John Paul II

* Emanuel Petrov, Ph.D., Catholic Faculty of Theology, University of Split. Address: ZrinskoFrankopanska 19, 21000 Split, Croatia. E-mail: donepetrov@gmail.com 